\title{
Is International Relations still an American social science discipline in Latin America?
}

Rafael A. Duarte Villa

Marilia Carolina B. de Souza Pimenta

\section{Introduction}

There are few academic articles regarding the way peripheral countries deal with both central production (including the epistemological and paradigmatic) and the perception of American hegemony in the discipline. The main assumption continues to be based on the research of Hoffman (1977), who asserts that the discipline of International Relations is basically an American social science; moreover, it is normally associated with the belief that international knowledge produced in the United States is spread and reproduced around the world, wherever the discipline is practiced.

The compelling consequence of Hoffmann's hypothesis, which was quickly transformed into a firmly rooted belief, is that the positivist epistemology and its paradigms (principally Realism and Liberalism) that are embedded in American social science are the main reference point for the discipline around the world. Smith underlines the fact that ideational thought in the world is "divided between the positivist theory that is practiced in the United States (...) and those, in various parts of the world, who are skeptical about the merits of Positivism" (Smith, 2002, p. 81). Consequently, the global debate appears to hold the epistemology, methods, and paradigms practiced in the United States as its core reference. Tickner and Weaver detect the lack of deeper research with a global perspective in International Relations theory, stating: "a limited number of studies have emerged on the contrast between the field of International Relations in the United States and Western Europe, but within a global perspective this is a ridiculously narrow view" (Tickner \& Weaver, 2009, p. 1).

Nevertheless, the question that remains unanswered (and is probably the most neglected) is: to what extent do the epistemology, methods, and paradigms that underlie research in developing countries follow the model of the dominant approach in the United States? It is reasonable to assume that American theoretical contributions, when incorporated into epistemic communities in other parts of the world, are subsumed and turned into invisible concepts and practices produced regionally. The impact that paradigms such as realism and liberalism had on researchers and decision-makers in Latin America seems to be undeniable, but to what extent were such paradigms incorporated in a basic or pure way among International Relations communities in Latin America? 
Latin American researchers (at least those belonging to the generations of the 70s, 80s, and 90s) cannot ignore the relevance of Dependency Theory, originally formulated by Cardoso and Falleto (1979) and presented in "Dependência e desenvolvimento na América Latina" (Dependency and Development in Latin America). It is reasonable to suppose that the concepts of the Theory of Dependence could have been entangled with Realist and Liberal ideas coming from the U.S., generating what Tickner (2002, 2009) called a "Latin Americanization of imported theories through a 'Latin America Hybrid model'-a fusion of concepts from dependency, realism and interdependence" (Tickner, 2009, p. 33-34, 2002). This conclusion is quite similar to that proposed by Maxi Schoeman, who investigated South Africa's community of International Relations scholars. When asked to respond to questions in a survey conducted by Schoeman, one professor of International Political Economy (IPE) said: "In IPE, in my opinion, we part ways with dominant Northern discourses. Dependency theory forms an important part of the curriculum to explore the politics of unequal development (...) I would argue that the way we teach (and were taught) IPE is with an intense sense of colonial and neo-colonial injustice" (Schoeman, 2009, p. 62).

At this point it is important to pose one question: to what extent does the theoretical debate-especially the so-called "third debate" between positivists and postpositivists-appear in Latin America? As Herz argues:

[t]he reflection on the history and nature of the discipline, which was so important for the development of the post-positivist debate in International Relations circles, did not take root in the region [Latin America]. Partly because most scholars working in the field presently graduated in social sciences, political science, history, or law, partly because the separation between international issues and domestic issues was never attainable in Latin America (Herz, 2010).

Generally, one more important question should be addressed: how is American influence perceived among Latin America communities of International Relations scholars with regard to both ideational and institutional influences and publications and contributions from American authors? Does Latin America still continue to be valid for the Hoffmann hypothesis?

This article uses as a starting point the data from the survey of the Teaching Research and International Policy (TRIP) project. The TRIP project has been in progress since 2004 and is hosted by the Institute for the Theory and Practice of International Relations, William \& Mary College. Today it includes more than 33 International Relations communities around the world. TRIP project initially examines relationships between the education process and research development and thus analyzes the possible influence that an epistemic community in International Relations can exercise over the foreign policy of a country, as well as what the perceptions of international politics are. Latin America became part of TRIP in 2011 as a result of one of the surveys, in which four 
RAFAEL A. DUARTE VILLA; MARILIA CAROLINA B. DE SOUZA PIMENTA

Latin American communities of International Relations scholars in Argentina, Brazil, Colombia, and Mexico were included (Maliniak et al., TRIP 2011). In the 2014 survey, Chile was also included.

The largest communities of international relations are those of Brazil and Mexico (both account for $73 \%$ of the total). In total the approximate size of the five communities is 835 researchers. The five communities investigated in Latin America totaled 445 respondents' researchers.

Table 1

Total of researchers and answers by country

\begin{tabular}{|l|c|c|c|}
\hline Countries & $\begin{array}{c}\text { Total researchers } \\
\text { by countries }\end{array}$ & $\begin{array}{c}\text { Respondents } \\
\text { over the total }\end{array}$ & $\begin{array}{c}\text { Response } \\
\text { rate (\%) }\end{array}$ \\
\hline Argentina & 82 & 47 & 57 \\
\hline Brazil & 321 & 211 & 66 \\
\hline Chile & 33 & 21 & 64 \\
\hline Colombia & 115 & 61 & 53 \\
\hline Mexico & 284 & 105 & 37 \\
\hline
\end{tabular}

Source: Elaborated by authors based on Maliniak et al., TRIP 2014 Faculty Survey.

Beginning with the selection of data on methodology, epistemology, paradigms, and perceptions of American hegemony in the discipline of International Relations, this article explores the following research problems: to what extent do the methodological, epistemological and paradigmatic trends in Latin America still adhere firmly to the Hoffmann hypothesis of American hegemony? To what extent do the ideas and institutions, and the most influential authors and journals continue to reproduce in Latin America Hoffmann's perspective, according to which International Relations is an American social science? Our initial hypothesis is that for both problems, the evidence, as revealed by the TRIP data, points to the answer being positive; however, first, there are important challenges to American dominance, primarily in epistemic and paradigmatic aspects. Secondly, there is no consensus among the Latin American epistemic communities as to the perception of the influence of the discipline of International Relations outside the United States; that is, to imagine an American social science in terms of what Hoffmann thought more than four decades ago.

This article is divided into two sections: in the first, we analyze data from the last survey, carried out in 2014, which is related to methodological, epistemological, and paradigmatic outcomes, and we present a theoretical discussion based on these outcomes. In the second section, based on the data related to several aspectsinstitution, authors, and journals-we discuss key challenges to Hoffmann's hypothesis of the outcomes among communities of International Relations scholars in Latin America. 


\section{Methodological, epistemological and paradigmatic challenges from Latin American scholarly communities}

In recent decades, there has been some debate between different scientific communities of Latin American social scientists over whether the strong influence of American quantitative methods would lead to different research designs among new generations of researchers (Barasoul \& Silva, 2016; Herz, 2010; Tickner, 2002, 2009). The discipline of International Relations did not escape this trend. However, is there strong evidence of such a quantitative trend in the 2014 TRIP data among Latin American communities?

Regarding methods, there is almost unanimous opinion that qualitative methodology is the most commonly used research tool. Except for Mexico and Brazil, 60 to $70 \%$ of the production of the rest of the countries utilizes qualitative methods. An important fact is that the methodology of policy analysis is felt to necessitate the use of more than quantitative methods, something counter to the idea of the strong penetration of quantitative methods in IR communities in the developing world. This finding is relevant as it shows the region is in line with what has been used in the United States, as well as demonstrating, even if indirectly, a latent resistance to the quantitative method.

Table 2

Key research methods by country

\begin{tabular}{|c|c|c|c|c|c|}
\hline Country & Argentina & Brazil & Chile & Colombia & Mexico \\
\hline $\begin{array}{c}\text { Main research } \\
\text { method }\end{array}$ & $\begin{array}{c}\text { Qualitative } \\
\text { analysis }\end{array}$ & $\begin{array}{c}\text { Qualitative } \\
\text { analysis } \\
\begin{array}{c}\text { Second main } \\
\text { research method }\end{array}\end{array}$ & Policy analysis & Policy analysis & Policy analysis \\
\hline analysis & Policy analysis & Policy analysis \\
\hline
\end{tabular}

Source: Elaborated by authors based on Maliniak et al., TRIP 2014 Faculty Survey.

More significantly, we can see that, as regards formal modeling, there is little penetration of these American methods into the IR community of Latin American internationalists, with as little as $5 \%$ at best reporting its use (as in Chile). There are communities that report usage near $0 \%$, such as Mexico, Colombia, and Brazil. This finding somehow belies the perception of members from epistemic communities in Latin America, according to which the quantitative would be the methodological mainstream in teaching and research institutions on Political Science and International Relations in Latin America. For example, in an analysis of the approaches of political science journals published in Argentina, Brazil and Mexico, Carpicu (2014) observed some tendencies to a 
RAFAEL A. DUARTE VILLA; MARILIA CAROLINA B. DE SOUZA PIMENTA

predominance of political science in the same way it is been produced in the United States. The author verified, thus, an empirical and quantitative orientation from the bibliographical production. Of the total of texts researched, $56.8 \%$ are empirical in nature, being that of this group, $54.3 \%$ use some quantitative technique.

An important observation to make at this point is that if these surveys correctly indicate preferences, then research using qualitative methods is not well represented, especially in those publications considered top journals. Editions of many journals come loaded with quantitative analysis articles or formal analyses, while articles with qualitative analyses are less numerous. Remember that International Political Sociology (IPS), one of the journals published by the International Studies Association (ISA), was conceived because of the demand from part of the community of International Relations scholars who complained about the excessive quantification or formalized analysis in the journals published by ISA (Villa \& Souza, 2014).

Therefore, if International Relations community members are reporting in large numbers their use of qualitative analysis and the use of policy analysis, we should be aware of three consequences: (i) first, there is a clear under-representation in top journals of studies using the methodological preferences of the majority of the International Relations community. This is a point that has been raised by Maliniak et al. (2011) and that the analysis of Latin American communities confirms. Second (ii), the fact that publishers prefer quantitative analysis and formalized articles already makes it difficult for part of the International Relations community to have articles accepted by the top American and European journals, which are published mainly in the United States, with a lesser number in Europe. This style is less accessible to researchers from Latin American countries, as mentioned above, because they are less trained to deal with analyses that use complex econometric and statistical calculations (Villa \& Souza, 2014). Finally, (iii) the epistemological data tends to strengthen aspects of the westernperiphery relations that the methodological analysis has already shown.

It is not uncommon to find phrases like "Rationalism dominates the mainstream literature of the discipline, especially in the United States" (Smith, 2000, p. 380 ) in the literature devoted to the theme of epistemological reflections. In epistemological terms, the data show a predominance of positivism. In four Latin American countries-Argentina, Chile, Colombia, and Mexico-epistemological positivism is the preference of communities, similar to the findings of TRIP 2011 (Tickner, Cepeda \& Bernal, 2012). This means that it is difficult to find consistency in Smith's argument "about the disbelief that prevails in many parts of the world about the merits of positivism." 


\section{Chart 1}

Position on positivism by country (\%)

\begin{tabular}{|c|c|c|c|c|}
\hline 23.8 & 29.0 & 25.0 & 27.1 & 28.6 \\
\hline 45.2 & 31.5 & 45.0 & 40.7 & 43.9 \\
\hline 31.0 & 39.5 & 30.0 & 32.2 & 27.6 \\
\hline \multirow[t]{2}{*}{ Argentina } & Brazil & Chile & Colombia & Mexico \\
\hline & Non-positivist & Positivist & Post-positivist & \\
\hline
\end{tabular}

Source: Elaborated by authors based on Maliniak et al., TRIP 2014 Faculty Survey.

However, even when it is correct to point out the dominance of positivism among Latin American communities, this finding is not sufficient to attest the Latin American community itself as positivist; for example, Brazil clashes with the positivist trend because it is the only country where the non-positivists outweigh the positivists. Also, Brazil is the country with the largest share of post-positivists (although close in percentage terms with other countries). Moreover, it is important to emphasize two aspects: first, the proportions in which the evaluated countries are divided according to the three epistemological categories (positivism, non-positivism, and post-positivism) show that general epistemological choices are diverse; thus, it may not be said that a category has been epistemologically erased. Second, the data tend to strengthen a certain 'epistemological hybridism:' this is because the positivist prevalence is balanced by the fact that the choices for non-positivism and post-positivism are high (accounting for about $55-60 \%$ of epistemological choices).

In fact, there is no epistemological purity, but epistemological diversity, as shown in Chart 1: there is a plurality of epistemological choices in the five Latin American research communities, taking into account that there is a reasonable minimum number of researchers who relate their scientific work exclusively to one of these three categories.

On the other hand, it is true that the average of the choices for non-positivism accounts for slightly more than one third. However, non-adherence to positivism does not necessarily indicate an attitude of open questioning of positivism (and its main exponents realism and liberalism), but could indicate that the research findings for alternative epistemological Positivism are not yet available. The most striking conclusion is that there is good acceptance of the post-positivist epistemological perspective among the five Latin American countries. It means that more than a quarter of the researchers on international relations could be called as post-positivists. 
RAFAEL A. DUARTE VILLA; MARILIA CAROLINA B. DE SOUZA PIMENTA

The tendency to hybridism tends to be reinforced by the question on the assumption of the rationality of the actors. There is a consensus among the five communities in declaring in high rates that their research is based both on assumptions of rationality of the actors as well as alternative approaches that do not assume the rationality of actors. So it is also significant that on average, almost one fifth of the respondents in the five Latin American countries (18\%) report that they do not assume the rationality of actors, which also challenges the other academic myth that the Latin American IR community is strongly rationalist.

Still on methodological aspects, one recurrent perception in theoretical studies is the dominance of the international framework of rational choice in the analyses. One of the consequences is that the assumption of rationality of the actors has displaced the third debate, from the dichotomy of positivist versus non-positivists, to the category rationalists versus not rationalists, currently recalled from the second debate. This has focused on the methodological aspects. Thus, the idea that scientific communities assumed rationality of the actors was largely disseminated. As Stephanie Neuman notes:

Rational choice theory has roved also problematic to an analytic tool in the Western setting (and to some social scientists in the Western setting too). It assumes that any chosen behavior can be understood as optimizing material self-interest. In class, many of my students and I wondered how can we make the assumption? Could that all decisions and human acts are a means to self-interested, material end in all cultures. How does one know this empirically? (...) Intuitively we felt the strength of a body of theory that ignores cultural variety is suspect (Neuman, 1998, p. 5).

In summary, in what regards epistemological aspects, the five Latin American communities seem to follow a dual pattern, which rests on the rationality of the actors for a lot of researchers, and does not assume rationality for many others. In this sense, they presented an average of $58.5 \%$ of respondents that assume the use of both different starting points to develop their research, as shown in Chart 2, and highlighted by Donald Puchala:

Contemporary Western thinking about international relations has had little to offer to explain, or to evaluate the significance of, the embittered tone, the complex motivations, the mythological underpinnings, or the historical dynamics of North-South relations. The main reason for this is that for a very long time (...) Western theorists have not been sufficiently concerned with the impact of the culture and ideas upon among states and people (Puchala 1998, p. 150). 


\section{Chart 2}

Percentage of respondents that assume both the rationality of actors and alternative approaches that do not assume the rationality of actors

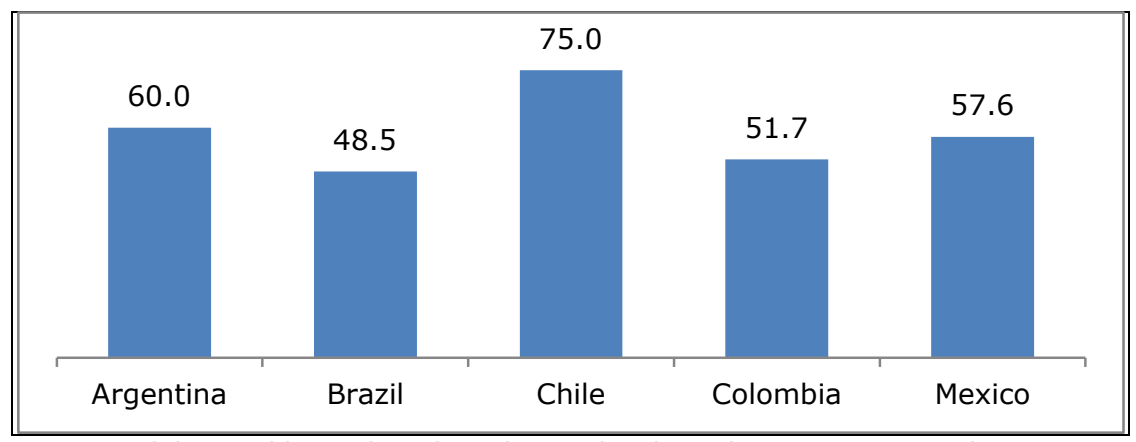

Source: Elaborated by authors based on Maliniak et al., TRIP 2014 Faculty Survey.

It is interesting to observe this dual standard in the research developed in the region, since most of it is influenced by critical perspectives and historical approaches; this is because, whether through French or English influence, or even that of historical materialism, communities eventually merge and blend different perceptions of the actors. This is also because they are sometimes rational and endowed with 'ideal' conditions for the decision making process, or sometimes the actor is circumscribed into a historical and material structure that impels him to act in a certain way and not another, and is considered more 'rational'.

Therefore, there is not a pure positivism (or 'puritan'), but a kind of theoretical syncretism, in which the core is a hegemonic theoretical amalgam according to local characteristics, or as pointed out by Tickner "geocultural epistemologies" that reproduce locally the hegemonic core (Tickner, 2009). A pure version of the mainstream theory condemns national communities of International Relations outside the United States and some European countries to an isolationist theory. An illustrative quote is helpful in that regard Stephen Walt's commentary on the persistent dominance of Anglo-Saxon scholarship in IR.

I'm still struck, [he states] by the relative dearth of 'big thinking' on global affairs from people outside the trans-Atlantic axis, including continental Europe. And by 'big thinking' I mean ideas and arguments that immediately trigger debates that cross national boundaries, and become key elements in a global conversation (Walt, 2011).

This type of theoretical miscegenation that challenges the possibility that 'pure theory' be reproduced beyond the IR core is fairly consistent with what Tickner (2009, 2002), Escudé (1998) and Ayoob (1998) respectively have called "Latin American hybridism", "peripheral theory" and "subaltern realism". As one Turkish scholar points out to Aydinli and Matthews: 
RAFAEL A. DUARTE VILLA; MARILIA CAROLINA B. DE SOUZA PIMENTA

you won't see an Alexander Wendt in Turkey because Wendt was writing from Wisconsin. In other words, even if actual theory construction does take place in Turkey, it will not likely be the same as that carried out by core IR scholars (Aydinli \& Matthews, 2009, p. 214).

The different views about paradigms also reinforce some of the trends observed in the methods and their epistemological aspects, as was possible to see here.

In terms of paradigms, with the exception of Mexico and Brazil, the IR communities of Latin America declare themselves to be mainly Constructivist, as can be seen in Chart 3. In Mexico, the preferences for realism are slightly higher than those for constructivism. However, it should be stressed again that these preferences exist within something like a paradigmatic hybridism (Tickner, 2009). With the exception of Chile, realism continues to be popular, and in some cases such as Argentina, Brazil and Mexico, the percentage of those who utilize this paradigm is not so different from those using the constructivist paradigm. Also, to a lesser extent, Liberalism, the English School and Marxism (the latter with the exception of Chile) also have a reasonable acceptance rate.

\section{Chart 3}

\section{Current paradigmatic choices by country (\%)}

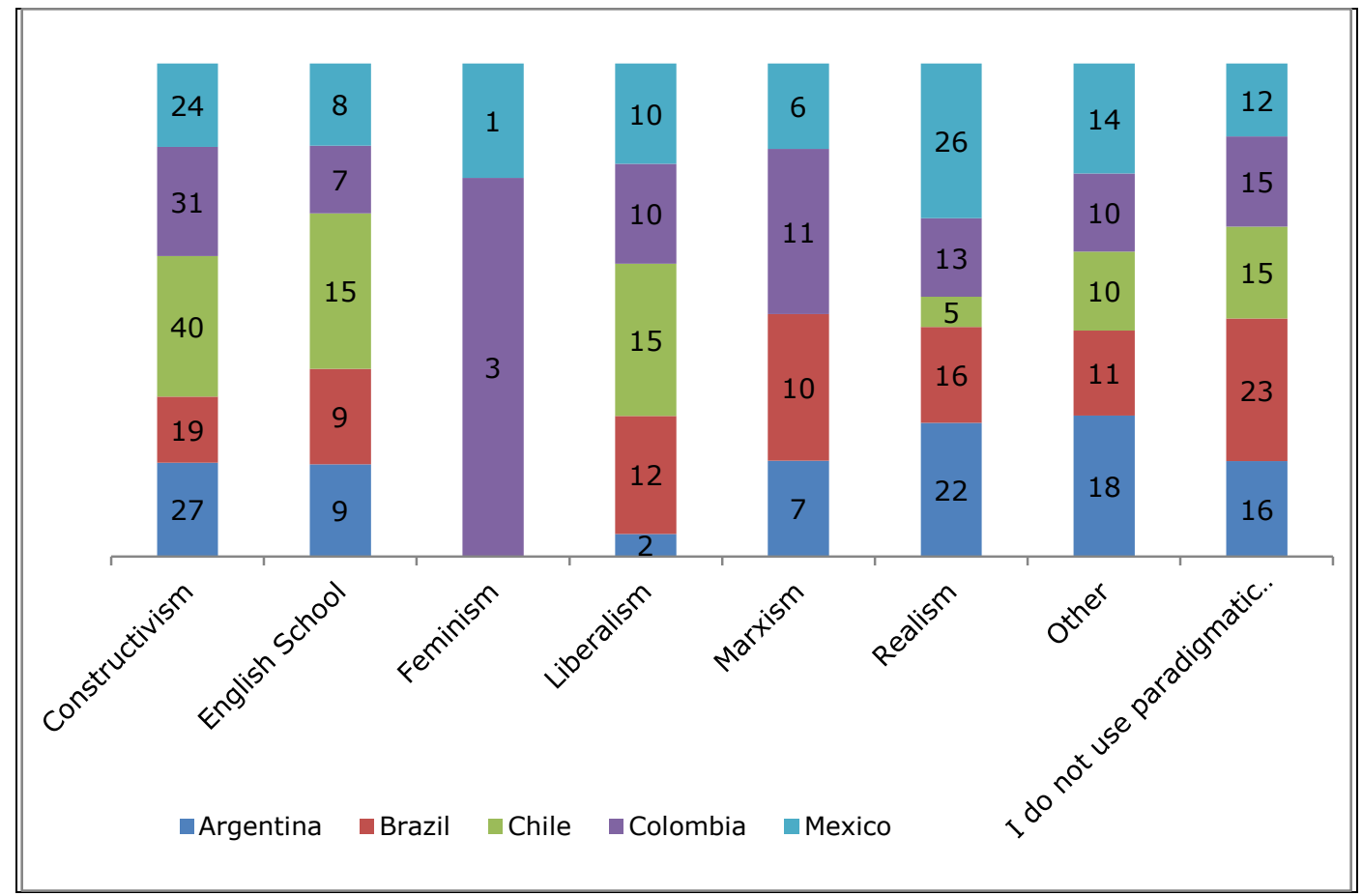

Source: Elaborated by authors based on Maliniak et al., TRIP 2014 Faculty Survey.

What could explain this preference for Constructivism? In order to comprehend this finding, it is important to recover the background of epistemological discussion 
through recent decades. We live in a time in which mainstream works have called attention to "the lack of a clear research program in the reflective agenda named nascent constructivism". According to Keohane, reflexivist approaches lack a "research program (...) [so] they would remain on the margins of the field, largely invisible to the preponderance of empirical researchers, most of whom explicitly or implicitly accept one or another version of rationalistic premises" (Keohane, 1988).

Contrary to Keohane's arguments, the popularity of Constructivism today is largely the result of the "boom" of Constructivism during the 1990s. Consequently, the focus of the epistemological and ontological debate has changed, and the target of epistemological 'denial' also has changed its focus. It is accepted that Constructivism, particularly its 'scientific version', affirmed by Wendt (summarized in the book Social Theory of International Politics, 1999), has achieved legitimacy in the positivist mainstream. Accordingly, Katzenstein, Keohane and Krasner (1998) heralded the emergence of a new debate, this time between Rationalism and Constructivism. In their words, Constructivism "offers a general theoretical orientation and specific research programs that can rival or complement rationalism" (Katzenstein, Keohane \& Krasner, 1998, p. 675). Or even "what separates critical constructivism and post-modernism is the acknowledgment by critical constructivists of the possibility of a social science and a willingness to engage openly in scholarly debate with rationalism" (Katzenstein, Keohane \& Krasner, 1998, p. 677).

On the other side of the argument, with the new axis of debate identified (Rationalist versus Constructivist), the post-Positivist became the place of 'the excluded' or 'exiles' and were labeled 'reflexivists' in the late $80 \mathrm{~s}$. Nevertheless, no other great debate arose in the 2000s. On the contrary, as Lake (2013) pointed out, what came in the 2000s was a certain disdain with great debates and the loss of space of the traditional positivist paradigm. Stephanie Newman - the author who has organized one of the few books focusing on the production of International Relations theory in the Third World - strengthens that idea:

Realism, neorealism, and neoliberalism are under attack from many quarters or many grounds, but the apparent fissure between theory and empirical reality in the Third World remains virtually unexamined. Even the so-called critical theorists, whose assaults on IR theory have been the most vigorous, have all but ignored these issues (Neuman, 1998, p. 2).

Similar arguments are raised by David Puchala:

[t]he experience of the Third World can be forced into the conceptual categories of conventional Western theorizing about International Relations. But the explanations that result are at least wanting in richness if not also in interpretive validity (...) A realistic analysis, for example, would reveal that in the world of states most of those in Asia, Africa, and Latin America are 
RAFAEL A. DUARTE VILLA; MARILIA CAROLINA B. DE SOUZA PIMENTA

deficient in power and most predominantly Third World societies are therefore inconsequential in world politics (Puchala, 1998, p. 149).

\section{Chart 4}

Use of paradigmatic analysis by country (\%)

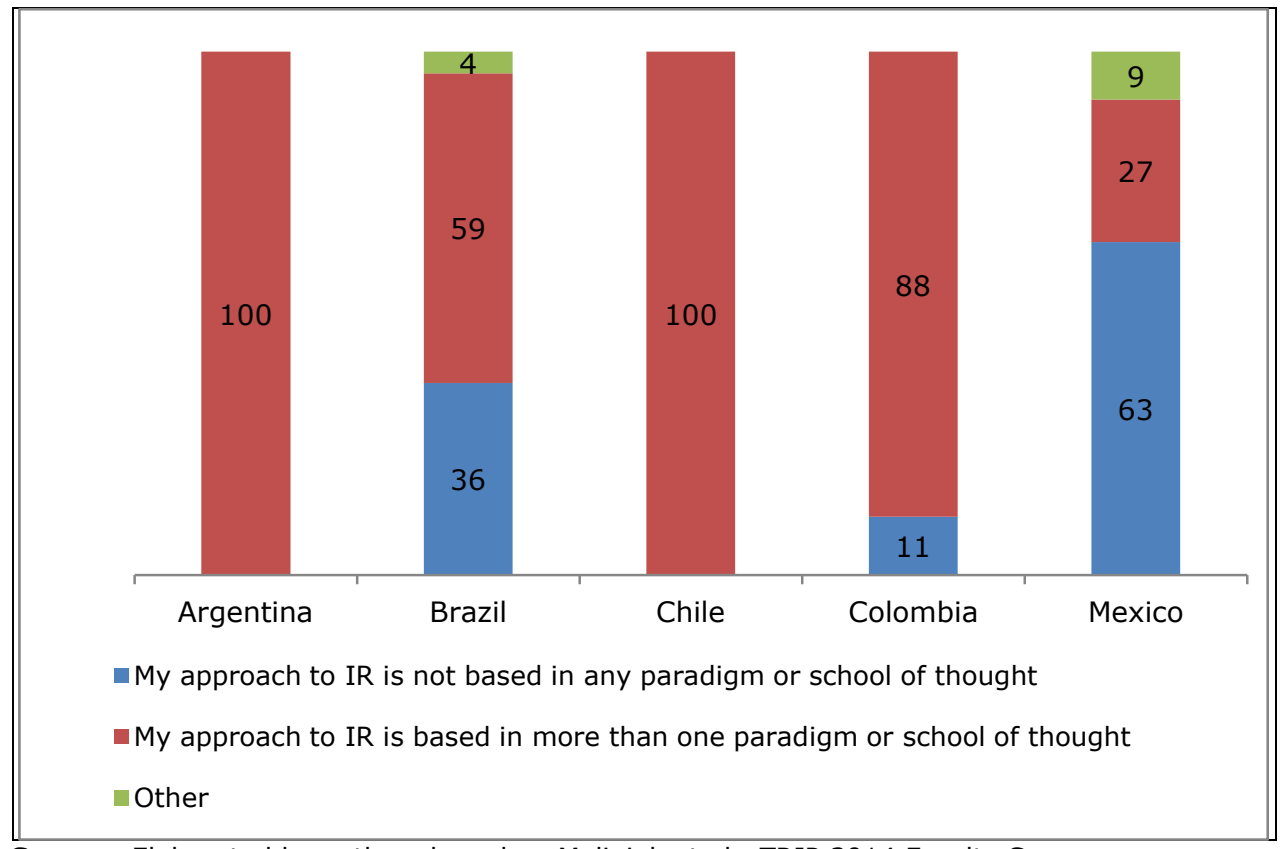

Source: Elaborated by authors based on Maliniak et al., TRIP 2014 Faculty Survey.

There seems to be a certain exhaustion of the 'monolithic' use of paradigms, at least in several of those national communities of researchers. And once more, the communities tend to affirm that their analyses are not necessarily tied to a single paradigm. In the four communities (except for Mexico), most respondents indicated in their responses that "My approach to IR is based on more than one paradigm or school of thought" as can be seen in Chart 4. In some cases, such as Argentina and Chile, $100 \%$ of the IR community adopts this position, and in cases like Brazil and Colombia, this percentage ranges from $59 \%$ to $88 \%$. In Brazil, one part of the community also claims not to adopt any paradigm (36\%)-this group represents more than a third of their IR community.

In other words, these data seem to take us far from the conclusion Smith arrived at: "the main debate in the discipline for the next decade will indeed be between rationalism and constructivism." (Smith, 2000, p. 380). According to other authors (Lake, 2013; Dunne, Hansen \& Wight, 2013; Brown, 2013) no other 'great debate' has arisen. The exhaustion and paradigms of debates formulated from the mainstream seems somewhat plausible. 


\section{Chart 5}

Initial paradigmatic choices by country (\%)

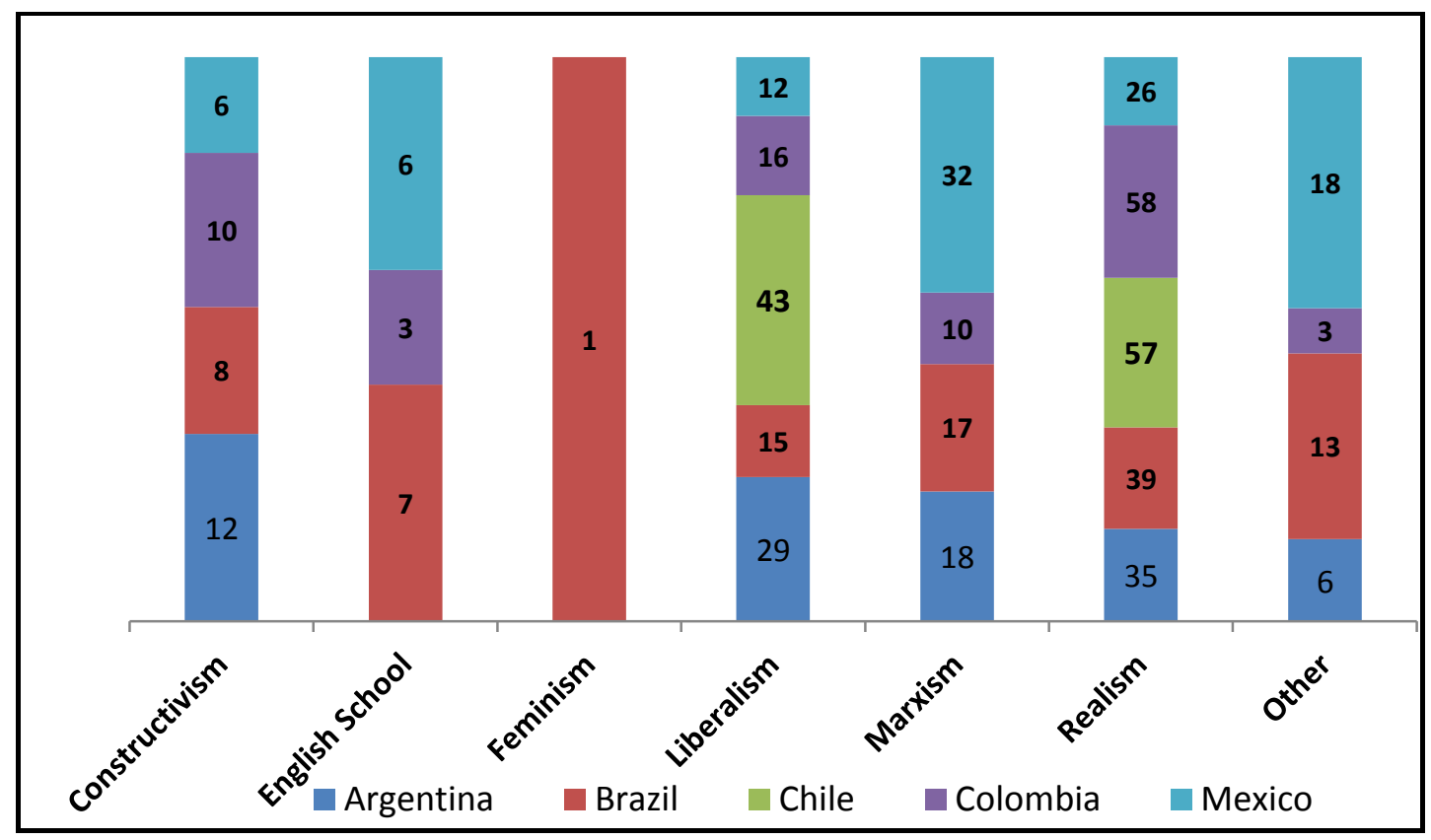

Source: Elaborated by authors based on Maliniak et al., TRIP 2014 Faculty Survey.

Some very relevant information is that, despite this hybridism, there has been a process of migration from traditional schools of thought (realism, liberalism, and Marxism) to alternatives (mainly constructivism and the English school) or "other," researchers who have left the traditional paradigm, but at the same time stating that "I do not use paradigmatic analysis". This migration has moved more strongly away from realism than any other traditional paradigm. Four of the analyzed communities (Argentina, Brazil, Colombia, and Chile) started with a strong reference to realism (actually more than a generation of scholars began in the IR discipline through realism). Including Mexico, where Marxism and realism were very influential, many of their researchers tend to have the same changing trend as recorded in other countries. In other words, the hybridism was also not a constant but a consequence, because the IR discipline was, in principle, very influenced by realism.

In sum, the Latin American communities surveyed tend to have a great diversity of epistemological perspectives and also tend to accept as many largely postpositivist paradigms as those who tend to migrate from the original paradigm. They move away from the theoretical biases of so-called mainstream debates more frequently than in the United States. Among these reasons we can enumerate: i) a high acceptance of sociological traditions; ii) a less intense involvement in academic intra-paradigmatic 
RAFAEL A. DUARTE VILLA; MARILIA CAROLINA B. DE SOUZA PIMENTA

rationalist debate (i.e. neo-realists and neo-institutionalists) and iii) these debates tend to arrive late from almost everywhere to the periphery (Villa \& Souza, 2014).

\section{The American influence on the discipline in Latin America}

As is well known among researchers of International Relations in the late seventies, Stanley Hoffman wrote a remarkable article in which he argued that International Relations was primarily an American discipline, signaling thereby the broad domain and influence of theories, paradigms, and methods practiced in the United States in regard to the universities of the rest of the world (Hoffman, 1977). This idea of the American prevalence among the discipline of International Relations is reinforced by cyclical production in the literature (Hoffman, 1977; Alker \& Bierstekerr, 1984; Holsti, 1985; Waever, 1998; Smith, 2000; Aydinli \& Matthews, 2000; Kristensen, 2012) that, since the work of Stanley Hoffman, has been tasked to disseminate and validate with evidence the idea that International Relations is an American science. There is, therefore, a predominance of epistemology, ontology, and methodology produced in the United States, with its strongly positivist and rationalist nature.

This reflection leads again to the following question: is the discipline of International Relations dominated by the United States in the Latin American cases studied. In the results observed from the analyzed data, one can see a dissonance among Latin American countries, particularly regarding Brazil's position, and to some extent in Mexico's position, as can be observed in Table 3:

Table 3

Perspective on the dominance of the United States in the discipline by country (\%)

\begin{tabular}{|l|c|c|c|c|c|}
\hline Opinion & Argentina & Brazil & Chile & Colombia & Mexico \\
\hline Strongly disagree & 9.09 & 22.77 & 0 & 5.88 & 4.65 \\
\hline Disagree & 13.64 & 57.43 & 9.09 & 8.82 & 32.56 \\
\hline Neither agree nor disagree & 22.73 & 1.98 & 9.09 & 11.76 & 13.95 \\
\hline Agree & 50 & 8.91 & 72.73 & 58.82 & 39.53 \\
\hline Strongly agree & 4.55 & 8.91 & 9.09 & 14.71 & 9.3 \\
\hline
\end{tabular}

Source: Elaborated by authors based on Maliniak et al., TRIP 2014 Faculty Survey.

In a clear example of the disagreement between epistemic communities in the Latin American region in Argentina, Chile, and Colombia, the majority considered International Relations a predominantly US discipline, especially in Chile. In Brazil, there is a notable percentage, approximately $80 \%$, who disagree or strongly disagree with this statement. Furthermore, Mexico's position showed that, although its community is so 
physically close to the United States, it is divided on the greater or lesser dominance of the US influence in the discipline.

On the question of the future of the discipline and the pursuit of greater autonomy from the American tradition, communities also tend to divide: Argentina, Chile and Colombia recognize American dominance (this does not mean they are not autonomous communities); on the other hand, the Brazilian community and the Mexican one in sequence seem to strive for disagreement as to the unchallenged predominance of the United States in the discipline. It is noteworthy, for now, that both communities are the majority in absolute terms in Latin America.

In addition to these perceptions on the relative dominance of the American discipline in Latin America, it is interesting to see what the expectations for researchers about doing a PhD in an American university are.

In terms of degree of educational background, Brazil and Mexico have the community with the most numerous PhDs. In addition, as they are the most numerous, both communities present the largest number of PhDs in absolute terms. Colombia and Argentina, in turn, are the countries with fewer PhDs, representing half or less of their communities. The conclusion that can be drawn is that there are asymmetries in the completion and absorption of PhDs throughout IR communities in Latin America. Furthermore, in general terms, there is a deficit of PhDs in the Latin American IR community. Even Brazil and Mexico hardly have high rates if one considers that in the United States the percentage of PhDs is $95.7 \%$ and in Turkey it is $93.48 \%$. The number of PhDs in some Latin American countries like Brazil and Argentina are comparable to India (and South Africa).

Table 4

Percentage of doctors and masters by country

\begin{tabular}{|l|c|c|}
\hline & Doctorate & Master \\
\hline Argentina & 50 & 34.78 \\
\hline Brazil & 78.33 & 16.26 \\
\hline Chile & 57.89 & 42.11 \\
\hline Colombia & 48.33 & 48.33 \\
\hline Mexico & 75.76 & 20.2 \\
\hline
\end{tabular}

Source: Elaborated by authors based on Maliniak et al., TRIP 2014 Faculty Survey.

These data above are related to how US institutional influence is perceived. It means that the deficit of PhD internationalists in Latin America is aggravated due to the strong belief Latin American researchers have in American universities and their leading doctoral programs in the field of International Relations. The data show a large convergence related to what the main doctoral programs for an academic career are. For the respondents, the choice of Harvard was predominant and present in all countries. In 
RAFAEL A. DUARTE VILLA; MARILIA CAROLINA B. DE SOUZA PIMENTA

sequence, the following are present in four countries: London School of Economics and Politics, Princeton and Oxford.

Such choices reflect a consensus among academics in the five countries of the region as to what they consider the best programs for the training of PhDs, and the data indicate a preponderance of American and British programs. Little is known in Latin America about the impact of PhDs who graduated in the U.S. and U.K./Europe on the Latin American national educational systems. Tickner (2009) signaled that till the end of the first decade of 2000 an overwhelming majority of professors who taught international relations at five leading institutions in Latin America area were earned their PhDs in the United States and Latin America: $33 \%$ in the United States; 50\% in Europe, and 16\% in Latin America or in-house. Such data about the North American and European programs reveal much about the lack of a greater number of qualified and highly institutionalized doctoral programs in Latin America in the field of IR.

This also shows an impact on the deficit of PhDs, and, certainly, in terms of impact on research and teaching, the fact that most of the PhDs are graduated in North America and Europe is relevant for understanding the origin from both nature and geographical socialization of epistemic, paradigmatic, and institutional influences that prevail among epistemic communities of international relations in Latin America. For example, some of the major and oldest PhDs programs in international relations in the region are in Brazil (at the University of Brasília and the Pontifical Catholic University of Rio de Janeiro). Yet these programs can be considered relatively new because they only date back to the early 2000s. 
Table 5

Doctoral programs leading to an academic career (\%)

\begin{tabular}{|c|c|c|c|c|c|c|c|c|c|}
\hline \multicolumn{2}{|c|}{ Argentina } & \multicolumn{2}{|l|}{ Brazil } & \multicolumn{2}{|l|}{ Chile } & \multicolumn{2}{|c|}{ Colombia } & \multicolumn{2}{|c|}{ Mexico } \\
\hline $\begin{array}{l}\text { Harvard } \\
\text { University }\end{array}$ & 65.0 & $\begin{array}{l}\text { Harvard } \\
\text { University }\end{array}$ & 62.0 & $\begin{array}{l}\text { Harvard } \\
\text { University }\end{array}$ & 62.0 & $\begin{array}{l}\text { Harvard } \\
\text { University }\end{array}$ & 76.0 & $\begin{array}{l}\text { Harvard } \\
\text { University }\end{array}$ & 69.1 \\
\hline $\begin{array}{l}\text { Columbia } \\
\text { University }\end{array}$ & 50.0 & $\begin{array}{c}\text { University of } \\
\text { Oxford }\end{array}$ & 46.3 & $\begin{array}{l}\text { University of } \\
\text { Oxford }\end{array}$ & 46.3 & $\begin{array}{c}\text { London } \\
\text { School of } \\
\text { Economics } \\
\text { and Political } \\
\text { Science }\end{array}$ & 52.0 & $\begin{array}{l}\text { Columbia } \\
\text { University }\end{array}$ & 47.3 \\
\hline $\begin{array}{l}\text { Princeton } \\
\text { University }\end{array}$ & 45.0 & $\begin{array}{c}\text { London } \\
\text { School of } \\
\text { Economics } \\
\text { and Political } \\
\text { Science } \\
\end{array}$ & 42.6 & $\begin{array}{c}\text { London } \\
\text { School of } \\
\text { Economics } \\
\text { and Political } \\
\text { Science } \\
\end{array}$ & 42.6 & $\begin{array}{c}\text { University of } \\
\text { Oxford }\end{array}$ & 44.0 & $\begin{array}{c}\text { Yale } \\
\text { University }\end{array}$ & 40.0 \\
\hline $\begin{array}{c}\text { London } \\
\text { School of } \\
\text { Economics } \\
\text { and Political } \\
\text { Science } \\
\end{array}$ & 35.0 & $\begin{array}{l}\text { University of } \\
\text { Cambridge }\end{array}$ & 35.2 & $\begin{array}{l}\text { University of } \\
\text { Cambridge }\end{array}$ & 35.2 & $\begin{array}{l}\text { Stanford } \\
\text { University }\end{array}$ & 40.0 & $\begin{array}{l}\text { University } \\
\text { of Oxford }\end{array}$ & 32.7 \\
\hline $\begin{array}{c}\text { Yale } \\
\text { University }\end{array}$ & 25.0 & $\begin{array}{l}\text { Princeton } \\
\text { University }\end{array}$ & 34.3 & $\begin{array}{l}\text { Princeton } \\
\text { University }\end{array}$ & 34.3 & $\begin{array}{c}\text { Yale } \\
\text { University }\end{array}$ & 32.0 & $\begin{array}{l}\text { Princeton } \\
\text { University }\end{array}$ & 30.9 \\
\hline
\end{tabular}

Source: Elaborated by authors based on Maliniak et al., TRIP 2014 Faculty Survey.

Another fact that has an impact on the perception of American dominance among Latin American communities of scholars in International Relations is derived from the institutional perception about the meaning of getting a PhD at an American university. It means that for the majority of the respondents; a student who has done their doctorate or part of it in the United States, is more likely to become a career academic than one who has studied only in their home country, as can be seen below:

Table 6

Greater or lesser expectation of success for those who obtain a PhD in the United States (\%)

\begin{tabular}{|rr|cr|rr|rr|rr|}
\hline \multicolumn{2}{|c|}{ Argentina } & \multicolumn{2}{|c|}{ Brazil } & \multicolumn{2}{c|}{ Chile } & \multicolumn{2}{c|}{ Colombia } & \multicolumn{2}{c|}{ Mexico } \\
\hline Yes & 52.3 & Yes & 49.7 & Yes & 83.3 & Yes & 79.7 & Yes & 59.6 \\
\hline No & 31.8 & No & 38.2 & No & 5.6 & No & 13.6 & No & 31.9 \\
\hline
\end{tabular}

Source: Elaborated by authors based on Maliniak et al., TRIP 2014 Faculty Survey.

It can be noticed that in almost all countries the majority in the academic communities believe that it is more likely that a student who has finished a doctorate in 
RAFAEL A. DUARTE VILLA; MARILIA CAROLINA B. DE SOUZA PIMENTA

the United States will have better chances of professional success. Therefore, there is a clear perception of how much value this adds to the student's intellectual development. However, there is a slight difference in terms of percentage balance among the academics in Argentina, Brazil, and Mexico on the one hand, and Chile and Colombia on the other, as observed in Table 6.

For Brazil and Mexico there is a majority who believe there is an increase and value in such experience in the U.S. Nevertheless, there are a significant number of researchers who do not believe this statement. That is, there are some researchers that don't necessarily believe that the young academics who conduct research in the United States will access their own labor market more easily than in other countries. Unlike in Chile and Colombia, the majority of researchers see the academic experience in the United States as an unquestionable gain in terms of comparative advantage to get a placement on return to any of these countries of origin.

How can one explain the difference among perceptions as concerns U.S. dominance over IR in the training of PhDs, especially when one considers the Brazilian case? It is also frequently assumed that communities outside the U.S. share the same level of training in International Relations. For instance, one thing that should be taken into account is the fact that the acquisition of theory in the developing countries may be filtered due to the inequality among local academic groups and also by the commitment to the theory of these groups. Aydinli and Matthews (2009) have called attention to the fact that in Turkey there is the division between one core group and one "non-elite" group and that this division "operated like a domestic core and periphery."

In addition, Tickner has also drawn attention to the same issue in Latin America:

The field may be described as a multi-tier structure in which distinct national and regional nodes coexist and sometimes overlap. To begin with, there is a small group of seated scholars primarily in Argentina, Brazil, Mexico, and Colombia at the top-notch universities that are highly integrated with the discipline's core, albeit in a subordinate role (Tickner, 2009, p. 45-46).

For this reason, it is important to note the conclusion reached by Thomas Biersteker: "the existence of an emerging global discipline of International Relations is contested, given the significance of the differences that remain among its many national and regional variations" (Biersteker, 1999, p. 3).

Conversely, the discussion on the American influence in Latin American communities can be seen from the other angle. It is regarding the most influential authors of International Relations. At this point, scholars in the region also tend to have similar views, as shown in Table 7. This becomes interesting to the extent that it turns out that everyone had and has access to global literature and shares a very close perspective to American and European scholars. 
Table 7

Most influential authors of the discipline of International Relations by country (\%)

\begin{tabular}{|c|c|c|c|c|c|c|c|c|c|}
\hline \multicolumn{2}{|c|}{ Argentina } & \multicolumn{2}{|c|}{ Brazil } & \multicolumn{2}{|l|}{ Chile } & \multicolumn{2}{|c|}{ Colombia } & \multicolumn{2}{|c|}{ Mexico } \\
\hline $\begin{array}{c}\text { Alexander } \\
\text { Wendt }\end{array}$ & 45.7 & $\begin{array}{c}\text { Alexander } \\
\text { Wendt }\end{array}$ & 35.3 & $\begin{array}{c}\text { Alexander } \\
\text { Wendt }\end{array}$ & 46.7 & $\begin{array}{c}\text { Alexander } \\
\text { Wendt }\end{array}$ & 48.1 & $\begin{array}{l}\text { Robert O. } \\
\text { Keohane }\end{array}$ & 28.4 \\
\hline $\begin{array}{l}\text { Robert O. } \\
\text { Keohane }\end{array}$ & 25.7 & $\begin{array}{l}\text { Joseph S. } \\
\text { Nye Jr. }\end{array}$ & 32.4 & $\begin{array}{c}\text { Joseph S. } \\
\text { Nye Jr }\end{array}$ & 40.0 & $\begin{array}{l}\text { Joseph S. } \\
\text { Nye Jr. }\end{array}$ & 30.8 & $\begin{array}{l}\text { Alexander } \\
\text { Wendt }\end{array}$ & 18.9 \\
\hline $\begin{array}{l}\text { Barry } \\
\text { Buzan }\end{array}$ & 25.7 & $\begin{array}{l}\text { Robert O. } \\
\text { Keohane }\end{array}$ & 30.0 & $\begin{array}{l}\text { Robert O. } \\
\text { Keohane }\end{array}$ & 33.3 & $\begin{array}{l}\text { Kenneth } \\
\text { Waltz }\end{array}$ & 25.0 & $\begin{array}{l}\text { Joseph S. } \\
\text { Nye Jr. }\end{array}$ & 17.6 \\
\hline $\begin{array}{c}\text { Robert W. } \\
\text { Cox }\end{array}$ & 20.0 & $\begin{array}{l}\text { Barry } \\
\text { Buzan }\end{array}$ & 27.1 & $\begin{array}{c}\text { Francis } \\
\text { Fukuyama } \\
\end{array}$ & 20.0 & $\begin{array}{l}\text { Barry } \\
\text { Buzan }\end{array}$ & 23.1 & $\begin{array}{c}\text { Kenneth } \\
\text { Waltz }\end{array}$ & 13.5 \\
\hline $\begin{array}{c}\text { Joseph S. } \\
\text { Nye Jr. }\end{array}$ & 20.0 & $\begin{array}{l}\text { Kenneth } \\
\text { Waltz }\end{array}$ & 21.2 & $\begin{array}{l}\text { Samuel P. } \\
\text { Huntington }\end{array}$ & 20.0 & $\begin{array}{l}\text { Robert O. } \\
\text { Keohane }\end{array}$ & 23.1 & $\begin{array}{l}\text { Samuel P. } \\
\text { Huntington }\end{array}$ & 10.8 \\
\hline
\end{tabular}

Source: Elaborated by authors based on Maliniak et al., TRIP 2014 Faculty Survey.

Three American authors, Alexander Wendt, Robert Keohane, and Joseph Nye Jr., respectively, lead the ranking in four countries. Following these, the authors Kenneth Waltz (also from the U.S.) and Barry Buzan (from Canada) are highlighted in three of the five countries. It is remarkable that in Argentina the author Robert Cox, an author out of the mainstream, also obtained a notable mention. As may appear in the TRIP survey of 2011, the first 10 scholars who are indicated as the ones that have influenced the field of International Relations are mostly from the U.S. (Maliniak et al., TRIP 2011; Villa \& Souza, 2014). There is no mention of authors from the developing world, including authors from Latin America.

Thus, one can note that such a group of influential authors, most in the liberal, realist, and constructivist camps, reinforces the idea among researchers and teachers in Latin American countries about which is the dominant epistemological perspective and what the paradigms that should be taught are.

On the other hand, the spread of the idea of the existence of three 'great debates' (realism vs. idealism; behavioral vs. non-behavioral realism; realism and positivism vs. post-positivism), may have had an effect on the contents of what is taught in the courses in Latin American institutions of International Relations. Therefore, it is not strange that an epistemologically-oriented perspective, which has had a direct effect in the International Relations theory courses at the graduate level, are so organized taking into account the dominant paradigms. This is not only because, evidently, the organization of courses should reflect hegemonic content that is accepted, but also because the idea that professors should not deprive students of the fundamental epistemological contents of their education, of course most positivist in nature, is consensual.

Similarly, introductory courses on International Relations theory are organized taking into account the general perception of the epistemological domain. In general, IR 
RAFAEL A. DUARTE VILLA; MARILIA CAROLINA B. DE SOUZA PIMENTA

theory education is focused on strong traditional paradigms, in descending order: realism, liberalism, constructivism, and Marxism (Maliniak et al., TRIP 2011). The reasons for this are the idea that a group of dominant paradigms arose in the last 50 years, mainly positivist in nature, and so it may be that the positivist literature is the most influential and widely disseminated at the international level. It is not uncommon in the literature to find phrases devoted to the thematic of epistemological reflections like, "Rationalism dominates the mainstream literature of the discipline, especially in the United States" (Smith, 2000, p. 380).

As a practical consequence, a program for graduate students in a course on International Relations in Latin America could never fail to include works such as Politics among Nations (Hans Morgenthau); Theory of International Politics (Kenneth Waltz); Power and Interdependence (Robert Keohane and Joseph Nye); After Hegemony (Robert Keohane); Social Theory of International Politics (Alexander Wendt); and The Tragedy of Great Powers (John Mearsheimer). The consequence for teaching in courses of IR for Latin America is an affirmation of the positivist literature. In her research, Tickner found that $53.3 \%$ of the leading IR theory courses in Latin America are organized on the basis of realism (classical and neorealist) and Liberalism (classical, interdependent, and neoliberalism). Other paradigms as Marxism and neo-Marxism are less used to teaching IR theory (Tickner, 2009, p. 42).

Such data mentioned above offset some optimism about the increase of graduate courses in international theory, research and production beyond the U.S. borders. As pointed out by Aydinli and Matthews:

The major common underlying factor behind these optimistic assertions has been the understanding that international studies outside the United States are flourishing (Aydinli \& Matthews, 2000, p. 291).

Nevertheless, it is still not clear what is the nature and content of the studies conducted in the periphery. In fact, a large number of works scrutinizing the epistemological production in international studies (the same stacking of arguments about the North American influence in discipline of International Relations) is based on the assumption that either other countries share the same ontological and epistemological views as the US, or they place themselves against North American theories by rejecting these views.

In fact, this assumption may be covering up the truth and/or could express a lack of knowledge of how the theory actually works in the rest of the world, especially outside of the United States. Firstly, the research conducted by Tickner in early 2000 has shown that International Relations courses taught in Latin America are mainly based on positivist frameworks. The majority of them include classic texts (state-centric and nonstate-centric) in their programs (Tickner, 2002, p. 92). When analyzing the case of Latin America, Monica Herz adds, 
The programs of courses on international relations theory are particularly similar to those found in North American or English-speaking universities. The inclusion of texts by authors from Latin American or from other regions is extremely rare (Herz, 2010, p. 1-2).

An American influence on Latin American communities can be qualitatively defined by observing the representation of scholars in international journals. Latin American scholars recognize some journals as those that publish articles with the greatest influence on the discipline. This is the reason why it is also important to ascertain which journals are considered the most influential to the IR discipline, in order to determine if the positions are also similar as proven with respect to the most influential authors in the field. In Table 8, we can analyze the percentage of choices for each journal separated by country.

Table 8

Most influential journals for the IR discipline

\begin{tabular}{|l|c|c|c|c|c|}
\hline Position & Argentina & Brasil & Chile & Colombia & Mexico \\
\hline $\mathbf{1}$ & $\begin{array}{c}\text { International } \\
\text { Organization }\end{array}$ & Foreign Affairs & Foreign Affairs & Foreign Affairs & Foreign Affairs \\
\hline $\mathbf{2}$ & $\begin{array}{c}\text { International } \\
\text { Security }\end{array}$ & $\begin{array}{c}\text { International } \\
\text { Organization }\end{array}$ & Foreign Policy & Foreign Policy & $\begin{array}{c}\text { International } \\
\text { Organization }\end{array}$ \\
\hline $\mathbf{3}$ & World Politics & RBPI & $\begin{array}{c}\text { International } \\
\text { Studies Quarterly }\end{array}$ & $\begin{array}{c}\text { International } \\
\text { Organization }\end{array}$ & Foreign Policy \\
\hline $\mathbf{4}$ & Millennium & $\begin{array}{c}\text { International } \\
\text { Security }\end{array}$ & World Politics & $\begin{array}{c}\text { American } \\
\text { Journal of } \\
\text { Political Science }\end{array}$ & $\begin{array}{c}\text { International } \\
\text { Security }\end{array}$ \\
\hline
\end{tabular}

Source: Elaborated by authors based on Maliniak et al., TRIP 2014 Faculty Survey.

International Relations community members strengthen the highlighted finding that the ranking of journals in the international academic world remains insular, focusing on American and European journals. In the pages of these journals, there is a strong dominance of American academics, or at least of academics working at American universities, confirming the results of a survey by Breuning, Bredehoft and Walton (2005). This also applies to some of the so-called "sub-disciplines" of International Relations, such as foreign policy analysis (Foreign Policy Analysis). For example, in a journal by the same name, between 2005 and 2010, 80\% of authors were working in American universities, with other authors based in institutions from the 'global north.' In other words, no article was written by authors from universities in the 'south:' neither in Brazil or any other country (Breuning, 2010).

By observing the data, we can see that the answers tend to be very similar, which also reflects an affinity in terms of choice of reference material, as well as a similar 
view about the main specialized publication in each area. From the above journals, the one that obtained more mentions was Foreign Affairs, with an average of $50 \%$. In order, International Organization and International Security obtained highlighted rankings in four of the five countries, averaging $32 \%$ and $27 \%$, respectively.

Journals closer to international policy than to theoretical discussions such as Foreign Affairs and, to a lesser degree, Foreign Policy, are recognized in four of the five cases in these rankings, which could be related to the fact that most Latin American Scholars consider that academia and policy practice should be linked. Brazil is the only case where scholars rank a national journal (Revista Brasileira de Política Internacional) as one of the most influential for discipline discussions, something that invites one to think about the development of the field in this country and its insertion into global debates. Argentina is the only country where a non-mainstream journal-Millennium-is considered among the top four influences in the discipline, which suggests that alternative and critical approaches are more valued for scholars from this country than their peers in the rest of Latin America.

Linguistic parochialism in international relations in the United States has helped to affirm in Latin American IR communities the idea of the selective relevance of authors, publications, and paradigms and, on the other hand, the irrelevance and invisibility of production elsewhere in the world. As Biersteker Thomas points out:

Linguistic parochialism has created equally vexing problems for the creation of a global discipline. Much of the literature on most theoretically sophisticated situations of Latin American dependency was simply out of reach for most Americans unable to read Spanish. Fernando Henrique Cardoso and Enzo Faletto's pioneering work 'Dependency and development in Latin America', originally written between 1965 and 1967 did not exist for most North Americans until the English language edition was published in 1979 (Biersteker, 1999, p. 6).

Perhaps nowadays it is not accurate to say that most of the discipline of International Relations is divided epistemologically, ontologically, and methodologically, but rather geographically. Much of the academic community is heard of in the 'great journals' only when the topic of the day in the United States is specifically about a country or a region, as Kristensen (2012) addresses. South American academics only tend to be heard when the matter being dealt with is South America itself.

However, it is important to note that parochialism may also be intensified because academics from South America do not communicate enough among themselves. The TRIP report for Latin America 2011 (Tickner, Cepeda \& Bernal, 2012) remarks, for example, that many among the most influential authors who teach and research at Latin American institutions do not research or teach in Brazil. And in this region, Brazil is the largest International Relations community. To be more precise, among the most influential authors from that report, there is a Brazilian who only teaches and researches 
in Argentina. Actually, this fact, presented by the TRIP Latin America report, does not seem to reveal that there are no influential Brazilian authors; on the contrary, their colleagues of Hispanic origin are unaware of, or do not read their works, as they are written in the Portuguese language.

In general, the trend in Latin American Communities is to recognize that it is almost a paradox that among the most influential journals, it is almost impossible to publish either an academic or policy-oriented article or essay. For example, until 2015, in what is considered the most prestigious academic journal in the International Relations area: International Organization (one of the journals published by the International Studies Association), only one Brazilian author published an article, and only as a coauthor.

The perception about American hegemony remains high among communities of International Relations researchers in Latin America. It is possible to measure it in many aspects (ideational, institutional paradigm) when it comes to the most influential authors and journals. However, there is some degree of dissidence, especially in the Brazilian community. It is certain that the interests in autonomous research, more institutionalization of the discipline, and the size of the community can be important factors for explaining said dissidence.

Additionally, in some cases, it may not be possible to dismiss the position of a country in the power structure. As for Brazil, the dissident position of its community could be related to the projection of the country in international politics, especially in the last 15 years, as it has become one of the ten largest economies in the world. It also has renewed its military systems and has set up political arrangements, such as the greater 'south-south' approach and the projection of its leadership in South America. Such phenomena may have stimulated the local community to leverage its position as regards American hegemony in the discipline.

\section{Conclusions}

In epistemological terms, the results of the 2014 TRIP survey show the predominance of positivism. In four Latin American countries, namely Argentina, Chile, Colombia, and Mexico-epistemological positivism is the preference of those academic communities. As was already evident in the 2011 TRIP, Brazil goes against this trend because it is the only country where the non-positivists outweigh the positivists. Also, Brazil is the country with the largest number of post-positivists (although close in proportional terms with other countries).

However, it is important to emphasize that the data showed by this article tend to strengthen the Hoffmann (1997) concept that the discipline of International Relations is indeed dominated by the epistemological, ontological, and methodological perspectives of the United States. In addition, American dominance is balanced by the fact that the choices for non-positivism and positivism are high. 
In other words, there is no American epistemological purity, but an American epistemological dominance that is balanced by other epistemological perspectives beyond the positivist ones present among the theoretical tools used by Latin American researchers, at least in those five countries evaluated. Nevertheless, the article highlights that Brazil seems to be the main dissident, and this is a relevant fact because in quantitative terms, the Brazilian community of International Relations academics is the most numerous among those in Latin America. As the 2014 TRIP data show, Brazil accounts for $45 \%$ of the members of these five Latin American epistemic communities of international relations (330 out of 830 ).

Certainly the theoretical miscegenation we observe doesn't mean a complete rupture with the U.S. mainstream, but it does mean adaptation to the comprehension of Latin American reality. As an example, some researchers from peripheral countries have been trying to mold core theories to the reality of their own countries.

By thinking of new categories, without renouncing the general premises of core theories, Carlos Escudé (1998, p. 56) assessed the thesis that the international system is not anarchic in peripheral countries; it is, on the other hand, a hierarchical system. To better understand the meaning of the substitution of 'anarchy' to 'hierarchy', Escudé proposed a 'peripheral theory', which he believes to be "the formulation of concepts, explanatory hypotheses, and normative judgments specifically applicable to peripheral states, that is, states relatively devoid of power resources" (1998, p. 56).

Mohammed Ayoob is another scholar who made an important contribution to the list of concepts that summarize the 'melting pot' of the Western perspective of the realities in the periphery, by proposing the concept of 'subaltern realism'. According to Ayoob (1998, p. 44-45), "the experience of the subalterns in the international system is largely ignored by the elitist historiography of the system popularized by neorealists and neoinstitutionalists".

Nevertheless, in terms of perceptions, the strength of the idea about the predominance of the United States remains powerful in the discipline. The IR communities of Argentina, Chile, and Colombia consider International Relations as a predominantly American discipline, especially Chile. Brazil is once again the main dissident. A high percentage of researchers disagree or strongly disagree with this statement about US hegemony in the field of $I R$, as popularized in the works elaborated by Hoffmann in the 1970s.

Rafael A. Duarte Villa - Political Science Department DCP-USP, Institute of International Relations IRI-USP, Director of the Center for Research in International Relations NUPRIUSP, University of São Paulo. E-mail: <rafaelvi@usp.br>.

Marilia Carolina B. de Souza Pimenta - PhD in International Relations and Researcher at the Center for Research in International Relations NUPRI-USP, Researcher at the Institute of International Economics Studies IEEI-UNESP, Anhembi Morumbi University-UAM, University Center FECAP. E-mail: <profa.marilia.csouza@gmail.com>. 


\section{Bibliographical references}

AlKer, H.; BIERSTeKerR, T. "The dialectics of world order: notes for a future archeologist of international savoir faire". International Studies Quarterly, 28(2), p. 121-142, Jun. 1984.

AYDINLI, E; MATTHEWS, J. "Are the core and the periphery irreconcilable? The curious world of publishing in contemporary International Relations". International Studies Perspectives, 1, p. 289303, 2000.

AYDINLI, E.; MATTHEWS, J. "Turkey: towards homegrown theorizing and building a disciplinary community". In: TICKNER, A.; WAEVER, O. (eds.). International Relations scholarship around the world. London \& New York: Routledge. 2009.

AYоов, M. Subaltern realism: International Relations theory meets the third world. In: NEUMAN, S. (ed.). International relations theory and the third world. New York: St. Martin's Press, p. 31-54, 1998.

BIERSTEKeR, T. "Eroding boundaries, contested terrain". International Studies Review, 1(1), Spring, p. 3-9, 1999.

Barasuol, F.; Silva, A. "International Relations theory in Brazil: trends and challenges in teaching and research". Revista Brasileira de Política Internacional, 59(2), e005, p. 1-20, 2016.

BREUNING, M. "Foreign policy analysis: an empirical assessment of the state of the art". Paper prepared for presentation at "Foreign Policy Agendas and Actors: Views from the North and the South". Institute of International Relations/Instituto de Relações Internacionais (IRI), Pontifícia Universidade Católica do Rio de Janeiro (PUC-Rio), Brazil, Sep. 8-9, 2010.

Breuning, M.; BRedehoft, J.; WALTON, E. "Promise and performance: an evaluation of journals in International Relations". International Studies Perspectives, 6(4), p. 447-461, Nov. 2005.

BRown, C. "The poverty of grand theory". European Journal of International Relations, 19(3), p. 483497, 2013.

CARdoso, F.; Faleto, E. Dependência e desenvolvimento na América Latina. Rio de Janeiro: Editora Zahar, 1979.

CARPICU, C. "¿Hacia una hegemonía del 'modelo mainstream norteamericano'? Enfoques de la ciencia política en América Latina (2000-2012)". Revista Latino-Americana de Investigación Crítica, 1 (1), p. $133-60,2014$.

DUNNE, T.; HANSEN, L.; Wight, C. "The end of International Relations theory?". European Journal of International Relations, 19(3), p. 405-425, 2013.

ESCUDÉ, C. An introduction to peripherical realism and its implications for the interstate system: Argentina and the Condor II Missile Project. In: NeUmAN, S. (ed.). International Relations theory and the third world. New York: St. Martin's Press, p. 55-75, 1998.

ESPACH, R. "International institutions: two approaches". International Studies Quarterly, 32(4), p. 379-396, 1988.

EsPACH, R. (ed.). Latin America in the new international system. Boulder: Lynne Rienner, 2001.

Goldstein, J.; KeOHANE, R. (eds.). Ideas \& foreign policy. Ithaca and London: Cornell University Press. 1993. 
RAFAEL A. DUARTE VILLA; MARILIA CAROLINA B. DE SOUZA PIMENTA

HERZ, M. "The study of international relations in Latin America". Symposium: "El Estado de la Disciplina de las Relaciones Internacionales en América". Rio de Janeiro, 2010.

Hoffmann, S. "An American social science: International Relations". Daedalus, 106 (3), p. 41-60, 1977.

HOLSTI, K. The dividing discipline: hegemony and diversity in international theory. London: Allen \& Unwin, 1985.

KEOHANE, R. Between vision and reality: variables in Latin American foreign policy. In: TULCHIN, J.; Espach, R. (eds.). Latin America in the New International System. Boulder: Lynne Rienner, 2001.

Katzenstein, P.; Keohane, R.; KRASner, S. "International organization and the study of world politics". International Organization, 52(4), Autumm, p. 645-685, 1998.

KRISTENSEN, P. "Dividing discipline: structures of communication in International Relations". International Studies Review, 14(1), p. 32-50, 2012.

LAKE, D. A. "Theory is dead, long live theory: the end of the great debates and the rise of eclecticism in International Relations". European Journal of International Relations, 19(3), p. 567-587, 2013.

LeHMAN, K.; LuCENA, C. IRI: "Pensando o futuro: objetivos e estratégias" (draft paper). Workshop: "Publicações e Impacto Acadêmico". Universidade de São Paulo, 2013.

MALINIAK, D., et al. TRIP 2014 Faculty Survey. Williamsburg, VA: Institute for the Theory and Practice of International Relations, 2014. Available at: <https://trip.wm.edu/charts/>. Acesso em: 5 Apr. 2017.

. TRIP 2011 Faculty Survey. Williamsburg, VA: Institute for the Theory and Practice of International Relations. Available at: <https://trip.wm.edu/home/index.php/surveys/facultysurvey>. Acesso em: 5 Apr. 2017. $\overline{437-464}, 2011$.

"International Relations in the US academy". International Studies Quarterly, 55(2), p.

NeUman, S. (ed.). International Relations theory and the third world. New York: St. Martin's Press, 1998.

. International Relations: theory and the third world: an oxymoron?. In: NeUmAN, S. (ed.). International Relations theory and the third world. New York: St. Martin's Press, p. 1-29, 1998.

OCHOA, L., et al. "La disciplina de las relaciones internacionales en México: enseñanza, enfoques y programas docentes". Ciudad de México: Benemerita/Amei/Feyri, 2013.

PuChaLA, D. Third world thinking and contemporary International Relations. In: Neuman, S. (ed.). International Relations theory and the third world. New York: St. Martin's Press, p. 133-157, 1998.

Schoeman, M. South Africa: between history and a hard place. In: TICKNer, A.; WaEVer, O. (eds.). International Relations scholarship around the world. London \& New York: Routledge, 2009.

Sмiтh, S. "The discipline of International Relations: still an American social science?". British Journal of Politics and International Relations, 2(3), p. 374-402, Oct. 2000.

"The United States and the discipline of International Relations: hegemonic country, hegemonic discipline". International Studies Review, 4(2), p. 67-85, 2002.

TICKNER, A. Los estudios internacionales en América Latina. CESO y Departamento de Ciencia Política de la Universidad de los Andes. Bogotá: Alfaomega Colombiana, 2002. 
IS INTERNATIONAL RELATIONS STILL AN AMERICAN SOCIAL SCIENCE DISCIPLINE IN LATIN AMERICA?

TICKNER, A. Latin America: still policy dependent after all these years?. In: TICKNER, A.; WAEVER, O. (eds.). International Relations scholarship around the world. London \& New York: Routledge, p. 32$52,2009$.

Tickner, A.; CepedA, C.; Bernal, J. Enseñanza, investigación y política internacional en América Latina. DDCP, 19. Documentos del Departamento de Ciencia Política, Universidad de los Andes, Bogotá, 2012.

TICKNER, A.; WAEVER, O. Introduction: geocultural epistemologies. In: TICKNER, A.; WeAVER, O. (eds.). International Relations scholarship around the world. London \& New York: Routledge, p. 1-31, 2009.

VILLA, R.; SouZA, M. "Communities of International Relations in emerging world: neither resistant to the positivism nor beyond debates". Journal of International Relations and Foreign Policy, 2(3,4), p. 67-97, Dec. 2014.

WALT, S. "Is IR still an 'American social science'?". Foreign Policy, Jun. 2011.

WEAVER, O. "The sociology of a not so international discipline: American and European developments in International Relations". International Organization, 52(4), Autumn, p. 687-727, 1998.

WendT, A. Social theory of international politics. Cambridge: Cambridge University Press, 1999.

\begin{abstract}
Is International Relations still an American social science discipline in Latin America?

Over the last 40 years, investigations have shown the discipline of International Relations to reproduce the American influence on its methods, paradigms, and institutional dynamics. This article explores the case for the Latin American community, based on the survey data from the Teaching, Research, and International Politics project (TRIP) 2014 developed by the Institute for the Theory and Practice of International Relations of the College of William and Mary, Virginia (USA). TRIP evaluated International Relations communities in 32 countries around the world. The article aims to answer two main questions: (i) is American influence still dominant over epistemological, methodological, paradigmatic, and institutional representative terms in Latin American International Relations communities, as has been considered in the past? (ii) Is there in the region any contestation to this supposed influence? Primarily, the present article shows an affirmative answer for the first issue. Therefore, and most importantly, the data analysis shows upcoming local pressures rooted in American influence, especially on its epistemic and paradigmatic terms. The data strengthens the miscegenation tendency on its epistemological and paradigmatic aspects, which underlines a lack of consensus over the structure of American dominance over the discipline of International Relations in Latin America, especially if one observes the most numerous and structured group in the region: the Brazilian International Relations community.
\end{abstract}

Keywords: TRIP; American influence; Latin America; International Relations

\title{
Resumo
}

As Relações Internacionais da América Latina ainda são uma disciplina das ciências sociais norteamericanas?

Nos últimos 40 anos, pesquisas mostraram que a disciplina de relações internacionais reproduz a influência norte-americana nos âmbitos da epistemologia, do método, dos paradigmas e dinâmicas institucionais. Este artigo visa a explorar o caso latino-americano, a partir da análise dos dados publicados pelo Teaching, Research and International Politics Project (TRIP) de 2014 do Instituto para a Teoria e Prática de Relações Internacionais do College William e Mary, Virginia (EUA), que pesquisa comunidades de relações internacionais em 32 países do mundo. $\mathrm{O}$ artigo tem por objetivo 
responder a duas questões principais: (i) se a influência norte-americana segue sendo dominante, em seus aspectos epistemológicos, paradigmáticos e de representações institucionais na região, tal como pesquisas no passado demonstraram; (ii) se existe contestação a tal influência na região. Em princípio, o artigo evidencia uma resposta positiva à primeira pergunta. Entretanto, e mais importante, a análise dos dados permite revelar a ascensão de questionamentos à influência norteamericana, sobretudo no que se refere aos aspectos epistêmicos e paradigmáticos. Os dados reforçam a tendência à miscigenação epistemológica e paradigmática e evidenciam não haver consenso quanto ao escopo de dominação norte-americana na comunidade latino-americana, especialmente por parte da comunidade epistêmica brasileira de relações internacionais, a mais numerosa e estruturada da região.

Palavras-chave: TRIP; influência americana; América Latina; Relações Internacionais

\section{Resumen}

¿Las Relaciones Internacionales en América Latina siguen siendo una disciplina de las ciencias sociales estadounidenses?

Investigaciones en los últimos 40 años señalan que la disciplina de Relaciones Internacionales reproduce en métodos, epistemología, paradigmas y dinámica institucional, la influencia estadounidense. El artículo busca explorar el caso Latino Americano, partiendo de los datos de la encuesta del Proyecto Teaching, Research and International Politics Project (TRIP) 2014 del Instituto para la Teoria y Práctica de Relaciones Internacionales del College of William and Mary, Virginia (USA), que investiga comunidades de Relaciones Internacionales en 32 países del mundo. El artículo pretende responder a dos preguntas: (i) si la influencia estadounidense sigue siendo dominante, en términos epistemológicos, paradigmáticos, y de representaciones institucionales en la región, como investigaciones del pasado señalaban (ii) si existe contestación en la región a tal influencia. El artículo muestra, en principio, que la respuesta puede ser afirmativa para la primera pregunta. Sin embargo, y es lo más importante, el análisis de los datos revela que están surgiendo presiones a la influencia estadounidense, sobre todo en los aspectos epistémicos y paradigmáticas. Los datos refuerzan la tendencia de mestizaje epistemológica y paradigmática, es decir, no hay consenso sobre el alcance de la dominación estadounidense en la comunidad de América Latina, especialmente por parte de la comunidad epistémica brasileña de Relaciones Internacionales, la más numerosa y estructurada de la región.

Palabras claves: TRIP; influencia estadounidense; América Latina; Relaciones Internacionales

\section{Résumé}

Les Relations Internationales en Amérique Latine sont-elles encore une discipline des sciences sociales aux États-Unis?

Au cours des 40 dernières années, plusieurs recherches ont montré que la discipline de Relations Internationales reproduit l'influence américaine dans les domaines de l'épistémologie, de la méthode, des paradigmes et des dynamiques institutionnelles. Cet article vise à explorer le cas de l'Amérique Latine, à partir de l'analyse des données publiées par le Projet d'enseignement, de recherche et de politique internationale (TRIP) 2014 de I'Institut pour la théorie et la pratique des Relations Internationales du Collège William et Mary, en Virginie (États-Unis), qui fait des recherches sur les communautés de relations internationales dans 32 pays à travers le monde. L'article vise à répondre à deux questions principales: (i) l'influence américaine reste dominante dans ses aspects épistémologiques, ses représentations paradigmatiques et institutionnelles dans la région, tel que la recherche I'a montré dans le passé; (ii) s'il y a objection à une telle influence dans la région. En principe, l'article met en évidence une réponse affirmative à la première question. Cependant, et d'une plus grande importance, l'analyse des données permet de révéler la montée des remise en question de l'influence américaine, en particulier en ce qui concerne les aspects épistémologiques et paradigmatiques. Les données renforcent la tendance à la miscégénation épistémologique et paradigmatique et montrent qu'il n'y a pas de consensus au sujet de la portée de la domination américaine au sein de la communauté latino-américaine, en particulier par la 
IS INTERNATIONAL RELATIONS STILL AN AMERICAN SOCIAL SCIENCE DISCIPLINE IN LATIN AMERICA?

communauté épistémique brésilienne des Relations Internationales, la plus nombreuse et structurée de la région.

Mots-clés: TRIP; influences américaines; Amérique Latine; Relations Internationales

Article submitted for publication on March 10, 2016.

Final version approved on March 21, 2017. 